\title{
Australian experience with cool season annual legumes - the challenge to develop environmentally sustainable farming systems
}

\author{
B.S. DEAR \\ CRC for Plant-based Management of Dryland Salinity, NSW Agriculture \\ Agricultural Institute, PMB, Pine Gully Rd, Wagga Wagga NSW, 2650 Australia \\ brian.dear@agric.nsw.gov.au
}

\begin{abstract}
Australian farming systems have traditionally relied on annual legumes such as subterranean clover (Trifolium subterraneum) and annual medics (Medicago spp.) in either short-term pastures in rotation with crops or permanent pastures to provide low cost biologically fixed $\mathrm{N}$ and a high quality forage for livestock. The role of legumes in farming systems is now being reassessed because of the recognition that their extensive use is associated with widespread soil acidification, loss of species diversity in native pastures and increasing dryland salinity. In the future, annual legumes are more likely to be sown in mixtures
\end{abstract}

with deep-rooted perennial pasture species, both in permanent pastures and in rotation with crops, to improve hydrological balance in the landscape. As a result, there is a change of direction in annual legume selection and breeding programs within Australia with a greater focus on the ability of legumes to coexist with perennial species, as well as on characteristics such as an extended growing season and deeper rooting habit to exploit subsoil water. There is also a trend towards increasing the diversity of annual legume species sown in pasture mixes to better exploit paddock variation and variable seasonal conditions.

Selection for ease of seed harvestability is becoming

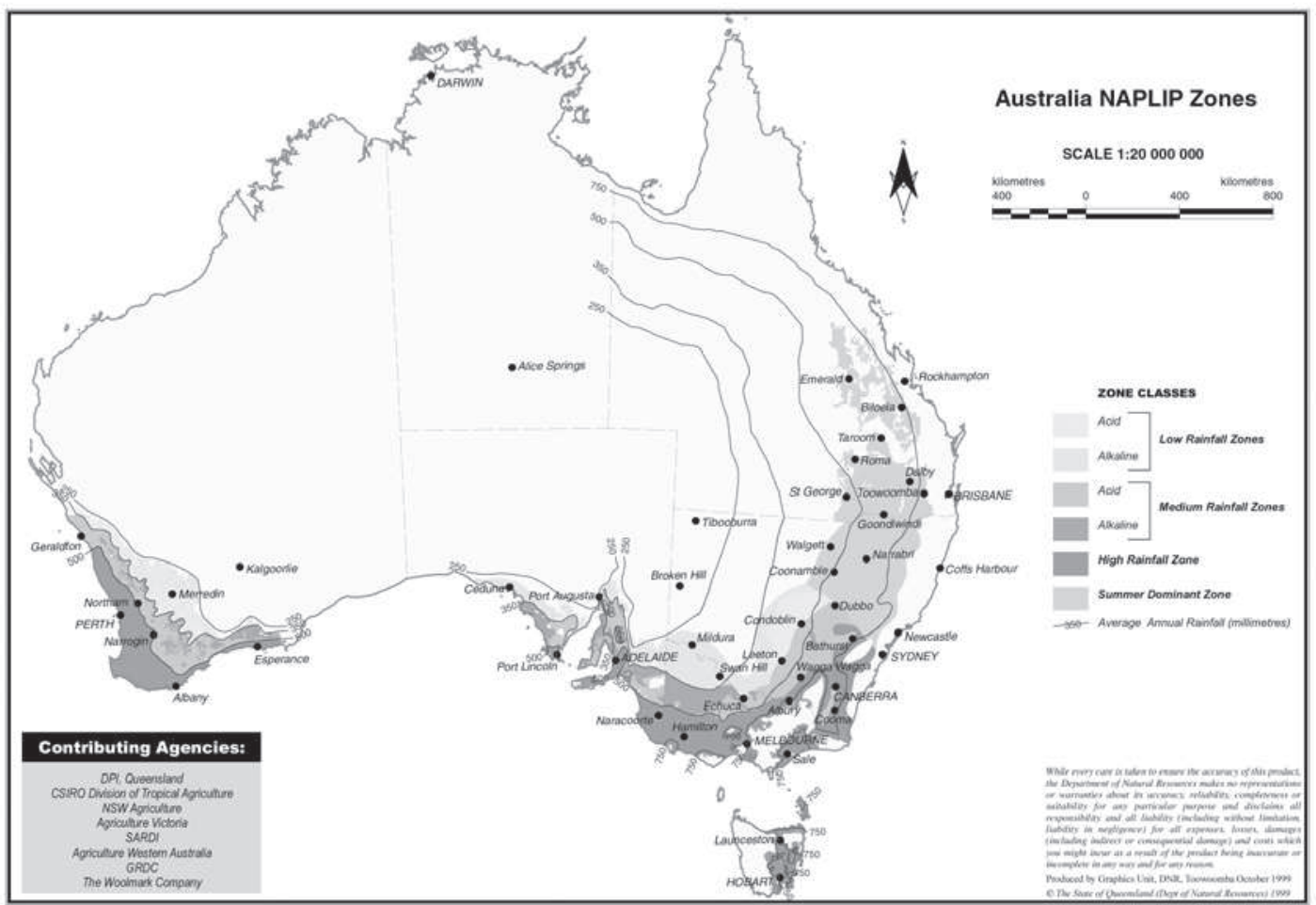

Figure 1 The agroecological zones where annual legumes are currently sown in southern Australia, subdivided on the basis of soil type and rainfall distribution. 
increasingly important to lower seed costs and reduce environmental damage associated with seed harvesting. The economic pressure to increase the intensity of cropping has led to an increased use of high density legume (HDL) forages grown as a one year disease break and $\mathrm{N}$ source, and the sowing of oat-legume mixtures for high quality forage or silage.

New annual legume species and cultivars recently released or under development include Trifolium glanduliferum, T. michelianum, T. resupinatum, $T$. isthmocapum, T. purpureum, T. hirsutum, $T$. formosum, T. diffusum, Biserrula pelecinus, Ornithopus sativus, and Melilotus albus.

Key words: annual legumes, balansa clover, biserrula, dryland salinity, gland clover, Moroccan clover, Persian clover, purple clover, serradella, subterranean clover

\section{Introduction}

Annual temperate pasture legumes such as subterranean clover (Trifolium subterraneum) or annual medics introduced from the Mediterranean region have been the main source of $\mathrm{N}$ in farming systems of southern Australia for over 60 years. The area sown in these legumes is estimated to exceed 17 million ha. Their dual role as a high quality feed for livestock, combined with their ability to restore soil $\mathrm{N}$ for both grazing and cropping industries, has ensured their central role in pastures across southern Australia. In extensive areas of non-arable hill country and tableland regions, the combination of subterranean clover and superphosphate has resulted in large increases in pasture productivity and stocking rates on native pastures. The area sown to annual legumes in Australia is shown in Figure 1. The area is subdivided based on soil type, $\mathrm{pH}$ and rainfall and these form the target zones for breeding new annual legume cultivars by the National Annual Pasture Legume Improvement Program (NAPLIP). NAPLIP is a consortium of State Departments of Agriculture, Universities and CSIRO, and is financially supported by producers through the Grains Research and Development Corporation and Australian Wool Innovation.

Subterranean clover is also sown in mixtures with cocksfoot (Dactylis glomerata), phalaris (Phalaris aquatica), perennial ryegrass (Lolium perenne) or tall fescue (Festuca arundinacea) in permanent pastures, but difficulty in readily establishing perennial grasses in rotation with crops has limited their use in cropping systems. Lucerne (Medicago sativa) is grown on about 3 million ha, mainly on better soils in the cropping zone, its further adoption being limited by lack of tolerance to waterlogging, soil acidity and inappropriate grazing practices.

\section{A new environmental perspective}

Farming systems incorporating annual legumes initially proved highly productive, however the increased supply of nitrogen and the inefficient use of rainfall by shallow rooted annual species led to extensive soil acidification (Helyar \& Porter 1989, Ridley et al. 2001), loss of species diversity in native pastures and the emergence of dryland salinity on a continental scale. The National Land and Water Resource Salinity Audit (NLWRA 2001), for example, recently estimated that 5.7 million ha are at risk or affected by dryland salinity in Australia in 2001, and the area is predicted to increase to 17 million ha in the next 50 years (Table 1). The present financial cost is estimated to be $\$ 230$ million p.a. in lost production and damage to infrastructure.

Soil acidification and rapidly increasing dryland salinity have been attributed to the inability of current farming systems based on shallow rooted annual species to cope with the change in water use and $\mathrm{N}$ cycling resulting from the removal of deep-rooted native perennial grasses, shrubs and trees. Although annual legumes from the Mediterranean region have proven well adapted to the southern Australian environment, their short growing season and shallow rooting behaviour resulted in a significant increase in the movement of water into the subsoil. This leads to large increases in deep drainage, acidification of the soil profile, as a result of nitrate leaching, and the mobilising of ancient stores of salt (Ridley et al. 1990) (Figure 2). Once the salt is mobilised in the ground water it either drains into rivers through aquifers, or if subsurface flows are interrupted, comes to the surface, causing salt scalds in lower lying areas.

The unsustainability of current farming practices based on annual species requires a revolution in landuse. New farming systems that better mimic the water use and nutrient cycling of the original native vegetation (Stirzaker et al. 2000) are required. Current estimates suggest that at least $40 \%$ of the landscape in southern Australia will need to be covered by deeprooted perennials, including lucerne, perennial grasses and herbs such as chicory (Cichorium intybus), if deep drainage to the ground water is to be reduced from current levels of $50-150 \mathrm{~mm}$ p.a. to 
around 4-7 mm p.a. (Figure 2). This is the estimated deep drainage that occurred under the original vegetation prior to clearing and the level considered necessary to achieve hydrological stability. Growers require a new range of perennial pasture plants that can be readily established in crop rotations and are tolerant of soil acidity, salinity, waterlogging or heavy grazing that limit use of existing perennial species. Similarly, an array of annual legumes that can successfully coexist with these perennial plants to provide the necessary $\mathrm{N}$ input must be developed.

While the problems associated with the widespread use of annuals in the landscape became apparent, there was also the view that most of the natural genetic potential of subterranean clover and annual medics had been largely exploited. Selection programs have made significant progress in lowering oestrogen levels, increasing disease resistance and manipulating hard seed levels, either raising them as insurance against "false breaks" or lowering them to compensate for the slower rates of softening in cool temperate environments (Evans \& Hall 1995). To make further progress towards the goals of increased species diversity and greater resilience to variable seasonal conditions, it was accepted that a new spectrum of annual legume species need to be domesticated to exploit a greater array of adaptive and reproductive mechanisms (Cocks \& Bennet 1998). These new annual species will also need to coexist with perennials, which will form the basis of pastures in the future.

In this paper recent progress in understanding the stresses experienced by annuals coexisting with perennials, new uses of annual legumes and recent cultivar releases, are discussed.

\section{New selection criteria for annual legumes}

Selection of annual legumes to coexist with perennial grasses and lucerne

Experience suggests that maintaining a vigorous annual legume component in phalaris or lucerne stands can be difficult, particularly in lower rainfall environments ( $<600 \mathrm{~mm})$ (Dear et al. 2001a). Typically, the annual legume component declines in mixtures with lucerne, leading to bare areas between plants and low winter sward productivity. Similarly, older phalaris and cocksfoot pastures often have a low annual legume component leading to $\mathrm{N}$ deficiency and a decline in feed quality and the vigour of the grasses.
Table 1 Areas (ha) with a high potential to develop dryland salinity in Australia.

\begin{tabular}{lcc}
\hline State & $1998 / 2000$ & 2050 \\
\hline New South Wales & 181000 & 1300000 \\
Victoria & 670000 & 3110000 \\
Queensland & not assessed & 3100000 \\
South Australia & 390000 & 600000 \\
Western Australia & 4363000 & 8800000 \\
Tasmania & 54000 & 90000 \\
\hline Total & 5658000 & 17000000
\end{tabular}

Source: National Land and Water Resources Audit 2001.

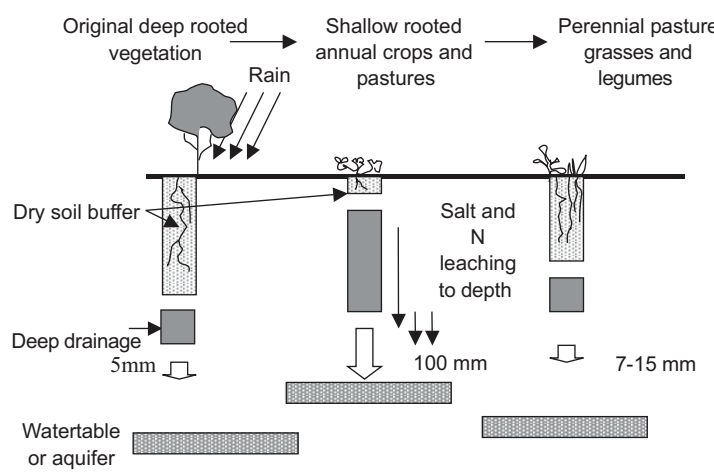

Figure 2 Diagrammatic representation of the change in deep drainage in the southern Australian landscape as a result of: 1) the removal of native vegetation, and 2) adoption of pasture/crop farming systems based on shallow-rooted annual pastures and crops. Expected drainage under perennial-based pastures is also shown.

To understand why annual legumes decline in mixtures with perennials it is important to identify the stages of the lifecycle that are susceptible to competition. The size of the seed pool at the end of summer is highly correlated with the number of clover seedlings that emerge in the following autumn (Dear et al. 2000). Hence any negative effects of perennial components on seed set (B in Figure 3) will decrease the proportion of annual legume in the subsequent sward. Perennials have been thought to reduce seed set of annuals through increased competition for soil water in spring during flowering and seed set. However recent work has shown that although perennials such as lucerne and phalaris dry the profile 


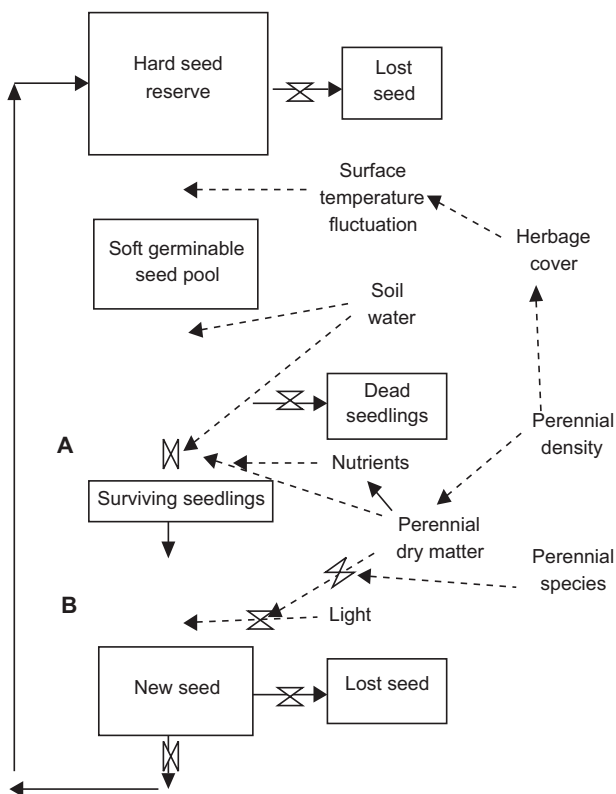

Figure 3 Subterranean clover life cycle stages that are susceptible to competition from perennial components of the sward. $A=$ seedling survival, $B=$ seed set.

below the annual root zone (Ridley et al. 1977), they have little effect on the rate of drying of that part of the soil profile $(0-40 \mathrm{~cm})$ exploited by annuals in spring (Dear et al. 2000).

There is good evidence, however, that shading of annual legumes in spring does suppress seed set, with the level of shading being a function of perennial density and biomass (Dear et al. 2000). Thus, minimising shading through grazing management is important to maximise clover seed set and long-term legume content.

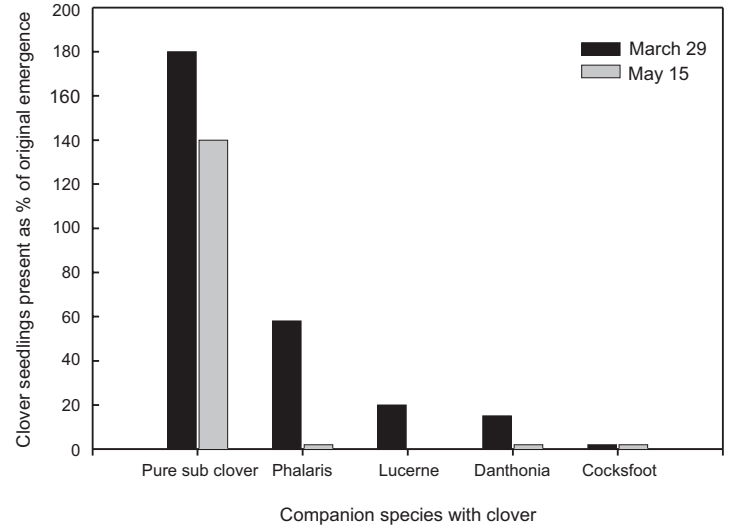

Figure 4 The percentage of clover seedlings that survived following an early autumn (late February) start to the season in mixed swards containing lucerne or perennial grass compared to clover monocultures. Source: Dear \& Cocks 1997.

Note: Additional seedlings emerged in annual plots after initial germination.

Annuals also appear particularly vulnerable to competition from perennials during seedling establishment in autumn (A in Figure 3). Competition from perennials during clover seedling emergence reduces the availability of mineral $\mathrm{N}$, light and water, and as a result severely restricts subterranean clover seedling growth rates and survival (Table 2) (Dear \& Cocks 1997; Dear et al. 1998). Significantly lower levels of available soil $\mathrm{N}$ in grass swards (Table 2) can restrain the growth of clover seedlings that have yet to effectively nodulate and rely heavily on mineral $\mathrm{N}$ for early growth.

The availability of soil water in perennial swards during autumn germination and emergence of annual

Table 2 The effect of lucerne and phalaris (relative to pure clover swards) on weight and turgor of subterranean clover seedlings following an early start to the growing season and differences in available soil $\mathrm{N}$ at cotyledon stage.

\begin{tabular}{lccc}
\hline Pasture type & $\begin{array}{c}\text { Seedling wt } \\
(\mathrm{mg} / \text { plant })\end{array}$ & $\begin{array}{c}\text { Seedling relative } \\
\text { water content }(\%)\end{array}$ & $\begin{array}{c}\text { Available soil } \\
\mathrm{N}(\mu \mathrm{g} \mathrm{N} / \mathrm{g} \text { soil })\end{array}$ \\
\hline \multicolumn{3}{c}{ 15 March } & 11 March \\
\hline Subterranean clover only & 2.02 & 74.5 & 32.7 \\
Phalaris/subterranean clover & 0.99 & 33.8 & 12.6 \\
Lucerne/subterranean clover & 0.56 & 29.3 & 12.6 \\
Least significant difference $(\alpha=0.05)$ & 0.32 & 0.22 & - \\
\hline
\end{tabular}

Source: Dear \& Cocks 1997 


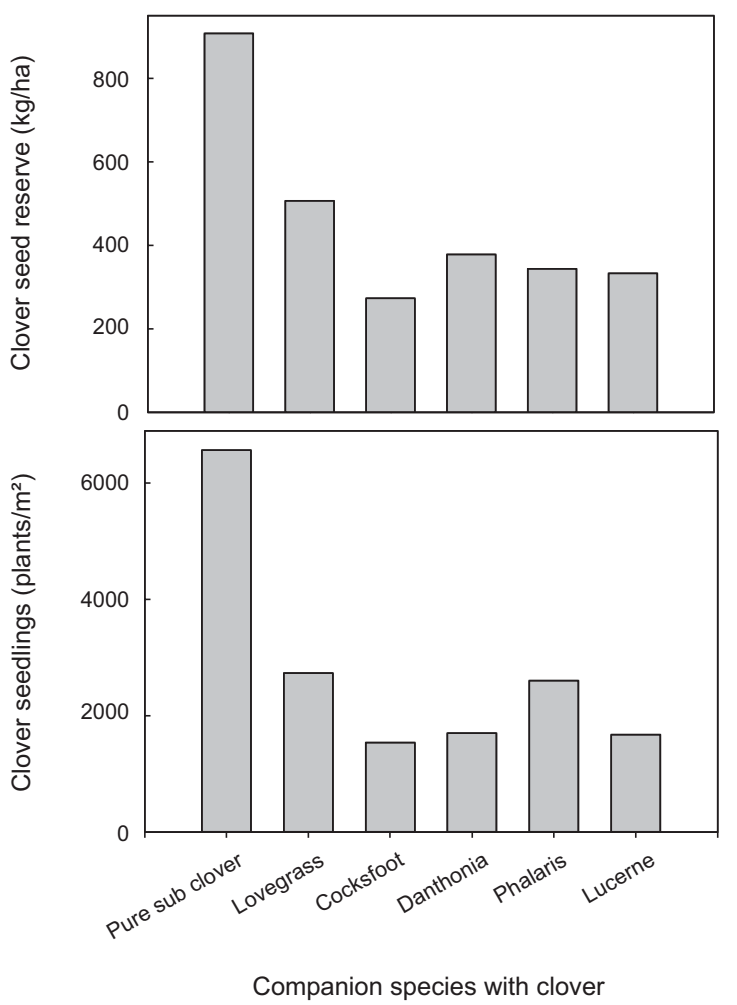

Figure 5 Effect of perennial grasses and lucerne on clover seed reserves and clover populations in winter in 4-year-old mixed swards compared with annual swards in a $600 \mathrm{~mm}$ rainfall environment. Source: Dear et al. 2001a.

legumes also influences their successful establishment. Lucerne and cocksfoot respond rapidly to late summer - early autumn rain when temperatures are still relatively high and can rapidly dry out the soil surface when subterranean clover is germinating, decreasing seedling turgor, size and survival (Table 2). Later in autumn, when prevailing temperatures are lower, phalaris is less restricted by high temperature dormancy and responds more rapidly, whereas lucerne is less responsive to these conditions. The rapid drying of the top $100 \mathrm{~mm}$ of soil by perennials can be an advantage if it prevents premature germination in late summer, but a disadvantage following autumn rainfall, where it increases the probability of "false breaks" (Dear \& Cocks 1997). The significant decrease in clover seedling survival in swards with perennials compared with pure annual swards following an early autumn rain is apparent in Figure 4. In annual swards, clover seedlings can continue to germinate and emerge over an extended period of time following rain, but the more rapid drying of the surface soil in perennial swards narrows the window for germination.

Once the "true" break of season occurred, clover seedling numbers in perennial swards were still significantly lower than in pure annual swards. The close relationship between seedling density and summer seed reserves reinforces the importance of maximising seed set in the previous summer (Figure $5)$.

Most Australian studies of annual and perennial mixtures have used subterranean clover as the annual component. There is some work, however, that suggests some annual legume species, such as $T$. hirtum, T. cherleri and T. pauciflorum, are better able to coexist with lucerne than subterranean clover $(\mathrm{G}$. Sandral pers. comm.). These findings are supported by a study by Dear et al. (2003a), who found the proportion of balansa clover (Trifolium michelianum) and annual medics increased significantly and the proportion of subterranean clover declined when lucerne was present in a sward. Future research should focus on identifying the attributes that allow some annual species to better coexist with perennials.

\section{Increasing water use by annual legumes}

Increasing the proportion of perennials in the sward is only one option for increasing water use. Alternative strategies include growing new annual legume species, such as biserrula (Biserrula pelecinus) and serradella, which may be better able to exploit deep subsoil water. Another approach is to grow later maturing species, such as purple clover (T. purpureum), with a longer growing season and the capacity to use water in late spring. A third strategy is to utilise alley farming techniques or wide row spacing, where annual legumes are combined with deep-rooting perennial grasses, perennial legumes or trees and shrubs, but where spatial arrangement is used to minimise interspecies competition while still achieving the desired hydrological outcomes (Stirzaker et al. 2002). In response to these needs, the newly formed Cooperative Research Centre for Plant-based Management of Dryland Salinity (PBMDS) is directing in excess of $\$ 2.5$ million/p.a. towards the selection of a range of new deep-rooted perennial legumes and grasses and the development of appropriate high water use farming systems. 


\section{Increased species diversity}

The great diversity of annual legumes found growing in close association in natural Mediterranean landscapes is in stark contrast to the monocultures or binary mixtures sown in Australian farming systems. More agronomists should seek to mimic this natural diversity in sown pastures to increase their adaptability to variations in aspect, soil type and drainage within a paddock, as well as to increase their resilience to seasonal variability. For example, by sowing three or more different legume species, such as balansa clover, subterranean clover and gland clover, in a mixture with perennial pasture legumes or grasses to provide more resilient and adaptable swards.

\section{Selection of salt and waterlogging tolerant species}

The increasing incidence of dryland salinity and rising water tables has increased the focus on selection of annual species with increased salt and waterlogging tolerance. These include selection for a greater range of maturities within balansa and Moroccan clovers (T. isthmocarpum), because both species exhibit superior tolerance to salinity and waterlogging. Selection of a low coumarin cultivar of sweet clover (Melilotus albus Medik.), 'Jota', is also welladvanced and targeted at saline and waterlogged soils (Evans \& Kearney 2003).

Balansa clover has been one of the most successful of these new waterlogging and saline tolerant species developed, with the area sown in southern Australia estimated to be over $1.5 \mathrm{~m}$ ha (Craig \& Ballard 2000). The release of the early flowering balansa clover cultivar, 'Frontier', (Craig et al. 2000) has extended its range into lower rainfall areas $(350-500 \mathrm{~mm})$ of the wheatbelt. The later maturing cultivar 'Bolta' is adapted to higher rainfall regions $(>600 \mathrm{~mm})$. Balansa clover has proven persistent in mixtures with lucerne on heavy clay soils prone to waterlogging (Dear et al. 2003a) and is becoming an important species for saline discharge areas.

Another new waterlogging tolerant legume close to release is 'Napier' subterranean clover. A member of the yanninicum subspecies, it has been selected for improved winter and spring productivity and is expected to replace 'Meteora' and 'Larisa'.

\section{Selection for ease of seed harvest}

Seed costs are a major factor restricting the adoption and use of new annual legumes. There is also public concern about the dust caused by harvesting subterranean clover burr. Thus researchers are intent on developing aerial seeding legume species that can be more easily harvested by farmers (Nutt et al. 1999). Small areas of pasture legumes within a paddock can be fenced off and allowed to flower and the seed harvested for use on-farm. Newly released annual species such as gland clover (T. glanduliferum), French serradella (Ornithopus sativus), and biserrula, are readily harvested by conventional machinery and offer significant potential for low cost seed production (Nutt et al. 1999).

The release of 'Cadiz' French serradella (Anon 1997) has been a major advance for sandy and loam soils where it has proven more able to exploit soil water deeper in the profile. The ability to readily harvest seed on farm with conventional crop harvesters has also assisted in its rapid adoption in the Western Australia and South Australia wheatbelts. The lack of hard seed in 'Cadiz' is a limitation in areas where summer rain causes premature germination and depletes seed reserves. Two new cultivars ('Margurita' and 'Erica') have been developed with increased levels of hard seed to overcome this problem (Dear et al. 2003b).

Biserulla is another new small-seeded annual species, with a deep-rooting habit that grows longer into spring than subterranean clover (Carr et al. 1999; Loi et al. 1999; 2000; 2001). It is being used successfully to control herbicide resistant ryegrass, as due to differences in palatability, sheep only graze the biserrula after consuming any ryegrass present.

The first cultivar of gland clover, 'Prima', was released in 2002 following a selection program by Brad Nutt at CLIMA (Dear et al. 2001b). It is unique for its very high level of resistance to blue-green aphids and redlegged earth mites (Wang et al. 1999), both serious pests of pastures in Australia.

\section{Use of legumes as short term forages}

\section{High density legumes (HDLs)}

The need for a high-yielding, high $\mathrm{N}$ fixing, one-year legume crop, which can also act as a disease break, has increased the sowing of legume combinations called high density legumes (HDLs). Typically three long season annual legume species are combined in a mix that conveys increased flexibility. It allows the 
Table 3 Herbage yield (t DM/ha) and invitro digestibility (\%) in parenthesis of legume or ryegrass monocultures and legume-oat mixtures at 3 cutting times.

\begin{tabular}{|c|c|c|c|c|c|c|}
\hline \multirow{3}{*}{$\begin{array}{l}\text { Forage } \\
\text { Pure legumes }\end{array}$} & \multicolumn{6}{|c|}{ Time of cut } \\
\hline & \multicolumn{2}{|c|}{ Early season } & \multicolumn{2}{|c|}{ Mid-season } & \multicolumn{2}{|c|}{ Late season } \\
\hline & Yield (t/ha) & Digest (\%) & Yield (t/ha) & Digest (\%) & Yield (t/ha) & Digest (\%) \\
\hline Berseem clover & 4.2 & $(76)$ & 7.1 & $(60)$ & 6.2 & $(50)$ \\
\hline Subterranean clover & 4.8 & (76) & 5.6 & (73) & 6.0 & $(70)$ \\
\hline Arrowleaf clover & 4.6 & (80) & 7.2 & (74) & 7.1 & $(67)$ \\
\hline Purple vetch & 6.2 & (74) & 9.8 & (68) & 9.2 & $(63)$ \\
\hline Field peas & 6.9 & (72) & 11.7 & (74) & 13.2 & (74) \\
\hline Ryegrass & 7.7 & (75) & 11.2 & (60) & 8.5 & (50) \\
\hline \multicolumn{7}{|l|}{ Mixtures } \\
\hline Berseem clover + oats & 6.5 & (68) & 11.0 & (61) & 13.3 & $(57)$ \\
\hline Subterranean clover + oats & 7.7 & (72) & 12.0 & (65) & 10.8 & $(60)$ \\
\hline Arrowleaf clover + oats & 7.3 & (70) & 10.2 & (63) & 9.8 & $(59)$ \\
\hline Purple vetch + oats & 8.3 & (71) & 14.8 & (65) & 11.1 & $(56)$ \\
\hline Field peas + oats & 9.5 & (74) & 14.8 & (68) & 12.8 & (60) \\
\hline Ryegrass + berseem & 5.4 & $(75)$ & 8.5 & (65) & 8.4 & (57) \\
\hline
\end{tabular}

Source: Dear et al. (1991)

legumes to be grazed in autumn-winter, closed up for hay or silage production, and depending on the season, the late regrowth can be grazed in NovemberDecember. Typical mixes and sowing rates include a combination of $3 \mathrm{~kg} /$ ha arrowleaf (T. vesiculosum), 3 $\mathrm{kg} / \mathrm{ha}$ Persian (T. resupinatum) and $6 \mathrm{~kg} / \mathrm{ha}$ berseem clover (T. alexandrinum).

\section{Oat-legume mixtures}

An alternative to these legume mixes, is the sowing of annual legumes with oats where maximising forage yield is a priority. Annual legumes such as berseem, arrowleaf or Persian clovers, vetches or field peas are grown with oats. Our research has shown that including oats significantly increases total biomass production but at the expense of forage quality (Table 3) (Dear et al. 1991).

\section{Conclusions}

Annual legumes will continue to play an important role in Australian farming systems, but the composition of pastures is expected to progressively change to address the sustainability issues associated with annual pastures. A greater diversity of annual legume species will be sown, often in mixtures with deep-rooted perennial grasses and legumes, to improve water use, reduce nitrate leaching and increase the resilience of pastures to environmental stresses. Greater emphasis will need to be given to maintaining annual legumes in mixtures with perennials to ensure the proportion of annual legume remains within desired limits. This will require a greater understanding of factors influencing competition between annuals and perennials in mixed swards and population dynamics in complex species mixtures.

\section{REFERENCES}

Anon. 1997. Variety: Cadiz syn ZAF5. Application No 96/019. Plant Varieties Journal 10: 2, 34-35.

Carr, S.J.; Loi, A.; Howieson, J.; Porqueddu C.; Etienne, M. 1999. Attributes of Biserrula pelecinus L. (biserrula): a new pasture legume for sustainable farming on acidic sandy soils in Mediterrranean environments. (Ed. L. Sulas). In: Legumes for Mediterranean forage crops, pastures and alternative uses, Proceedings 10th Meeting of Mediterranean sub-network of the FAO-CIHEAM Inter-regional Cooperative Network on Pastures and Fodder Crops Vol 45, CHIEM, FAO, Universita degli Studi di Sassari, CNR, Zaragoza. 
Cocks, P.S.; Bennet, S.J. 1998. Genetic resources of Mediterranean pasture and forage legumes. In: Current plant science and biotechnology in agriculture 33. Kluwer, Dordrecht, Netherlands.

Craig, A.D.; Ballard, R.A. 2000. Balansa clover (Trifolium michelianum) - a forage legume for temperate pastures. pp. 177-180. (Ed. L. Sulas) In: Legumes for Mediterranean forage crops, pastures and alternative uses, Proceedings 10th Meeting of Mediterranean sub-network of the FAO-CIHEAM Inter-regional Cooperative Network on Pastures and Fodder Crops Vol 45, CHIEM, FAO, Universita degli Studi di Sassari, CNR, Zaragoza.

Craig, A.D.; Sandral, G.A.; Dear, B.S.; Latta, R.A.; Evans, P.M.; Hill, N.L. 2000. Register of Australian Herbage Plant Cultivars. B. legumes. 1. clover. Trifolium michelianum Savi (balansa clover) cv. Frontier Reg. No. B-1j-3. Australian Journal of Experimental Agriculture 40: 1201-1202.

Dear, B.S.; Hayes R.C.; Sandral, G.A.; Swan, R.; Peoples, M.B.; Orchard B.; Chan K.Y.; Oates, A. 2003a. The change in the proportions of annual legume species in response to the presence of lucerne and the addition of gypsum. In: Proceedings $11^{\text {th }}$ Australian Agronomy Conference, Australian Society of Agronomy, http://www.regional.org.au/au/asa/2003/c/14/ dear.htm.

Dear, B.S.; Cocks, P.S. 1997. Effect of perennial pasture species on surface soil moisture and early growth and survival of subterranean clover (Trifolium subterraneum L.) seedlings. Australian Journal of Agricultural Research 48: 683-93.

Dear, B.S.; Cocks, P.S.; Swan,A.D.; Wolfe, E.C.; Ayre, L.M. 2000. Effect of phalaris (Phalaris aquatica L) and lucerne (Medicago sativa L) density on seed yield and regeneration of subterranean clover (Trifolium subterraneum L). Australian Journal of Agricultural Research 51: 267 - 78.

Dear, B.S.; Cocks, P.S.; Wolfe, E.C.; Collins, D.P. 1998. Established perennial grasses reduce the growth of emerging subterranean clover seedlings through competition for water, light and nutrients. Australian Journal of Agricultural Research 49: 41-51.

Dear, B.S.; Kaiser, A.G.; Simmul, L.K. 1991. High quality winter forages for the feedlot industry. pp 13-17. In: Advances in fodder conservation- silage and hay. NSW Agriculture, Orange, NSW.

Dear, B.S.; Sandral, G.A.; Nutt, B.; Wilson, B.; Rodham, C.; Taylor, J. 2001b. Gland clover- a new insect resistant legume. p 63-64. In: Proceedings $16^{\text {th }}$
Annual Conference of the Grasslands Society of NSW. Gundagai. Ed. Condon, K. Grassland Society of NSW, Wagga Wagga, NSW.

Dear, B.S.; Sandral, G.A.; Nutt, B.; Wilson, B.C.D.; Taylor, J.N.; Rodham, C.A. 2003b. New hardseeded French serradella cultivars (Ornithopus sativus Brot.). pp. 94. In: Proceedings of the First Joint Conference of the Grassland Societies of Victoria and NSW. Grassland Society of Victoria. Mornington, Victoria.

Dear, B.S.; Sandral, G.A.; Wilson, B.C.D.; Rodham, C.A.; McCaskie, P. 2003c. Productivity and persistence of Trifolium hirtum, T. michelianum, T. glanduliferum and Ornithopus sativus sown as monocultures or in mixtures with $T$. subterraneum in the south-eastern Australian wheat-belt. Australian Journal of Experimental Agriculture 42: 549-556.

Dear, B.S.; Virgona, J.M.; Sandral, G.A.; Swan, A.D.; Orchard, B. 2001a. Effect of companion perennial grasses and lucerne on seed yield and regeneration of subterranean clover in two wheatbelt environments. Australian Journal of Agricultural Research 52: 973-983.

Evans, P.M.; Smith, F.A. 1999. Patterns of seed softening in subterranean clover in a cool, temperate environment. Agronomy Journal 91: 122-127.

Evans, P.M.; Hall, E.J. 1995. Seed softening patterns from single seed crops of subterranean clover (Trifolium subterraneum L.) in a cool temperate environment. Australian Journal of Experimental Agriculture 35: 1117-127.

Evans, P.M.; Kearney, G.A. 2003. Melilotus albus (Medik.) is productive and regenerates well on saline soils of neutral to alkaline reaction in the high rainfall zone of south-western Victoria. Australian Journal of Experimental Research 43: 349-355.

Helyar, K.R.; Porter, W.A. 1989. Soil acidification, its measurement and the processes involved. pp. 61101. In: Soil acidity and plant growth. Ed. Robson, A.D. Academic Press, Sydney.

Loi, A.; Cocks, P.S.; Howieson, J.G.; Carr, S.J. 1999. Hardseededness and the pattern of seed softening in Biserrula pelecinus L. Onithopus compressus L. and Trifolium subterraneum seeds. Australian Journal of Agricultural Research 50: 1073-1081.

Loi, A.; Howieson, J.H.; Carr, S.J. 2001. Registrar of Australian herbage plant cultivars: B. Legumes; 25. Biserrula; biserrula pelecinus L. (biserrula) cv. Casbah. Australian Journal of Experimental Research 41: 841-842.

Loi, A.; Nutt, B.J.; McRobb, R.; Ewing, M.A. 2000. 
Potential new alternative annual pasture legumes for Australian Mediterranean farming system. pp 51-54. (Ed. L. Sulas) In: Legumes for Mediterranean forage crops, pastures and alternative uses Proceedings 10th Meeting of Mediterranean sub-network of the FAO-CIHEAM Inter-regional Cooperative Network on Pastures and Fodder Crops Vol 45, CHIEM, FAO, Universita degli Studi di Sassari, CNR: Zaragoza.

National Land and Water Resources Audit. 2001. Australian dryland salinity assessment 2000; Extent, Impacts, Processes, Monitoring and Management Options. Land and Water Australia, Canberra.

Nutt, B.J.; Loi, A.; Falcinelli, M.; Rosellini, D. 1999. Harvestability of annual Mediterranean pasture legumes using conventional crop machinery. Herbage seed set as a key factor for improving production and environmental quality. pp 78-82. In: Proceedings Fourth International Herbage Seed Conference, Perugia, Italy, University of di Perugia; Perugia, Italy.

Ridley, A.M.; Christy, B.; Dunin, F.X.; Haines, P.J.; Wilson, K.F.; Ellington, A. 2001. Lucerne in crop rotations on the Riverine Plains. 1. The soil water balance. Australian Journal of Agricultural Research 52: 263-277.
Ridley, A.M.; Helyar, K.R.; Slattery, W.J. 1990. Soil acidification under subterranean clover (Trifolium subterraneum L.) pastures in north-eastern Victoria. Australian Journal of Experimental Research 30: 195-220.

Ridley, A.M.; White, R.E.; Simpson, R.J.; Callinan, L. 1977. Water use and drainage under phalaris, cocksfoot, and annual ryegrass pastures. Australian Journal of Agricultural Research 48: 1011-1023.

Stirzaker, R.; Lefroy, T.; Keating, B.; Williams, J. 2000. A revolution land use: emerging land use systems for managing dryland salinity. CSIRO, Canberra.

Stirzaker, R.; Vertessy, R.; Sarre, A. 2002. Trees, water and salt: an Australian guide to using trees for healthy catchments and productive farms. Rural Industries Research and Development Corporation, Canberra.

Wang, S.; Ridsdill-Smith T.J.; Ghisalberti, E.L. 1999. Host resistance in Trifolium glanduliferum to redlegged earth mite, Halotydeus destructor. pp. 268-271. In: Proceedings of $7^{\text {th }}$ Australasian Conference on Grassland Invertebrate Ecology. CSIRO Entomology, CSIRO Centre for Mediterranean Agricultural Research, Wembley, Australia. 
